\title{
Teaching the unknown to facilitate the emergence of a pedagogical event
}

Fernando Hernández-Hernández, University of Barcelona

\begin{abstract}
I have organized this article in two parts. First, I present some of the main concepts that illustrate the praxis of my teaching and researching task. These are concepts that help me build my positionality to cope with the unknown and move through the disturbances of the pedagogical relations at the University. In the second part, to illustrate how these concepts are performing in a collaborative teaching and researching process, I present a case developed with a group of undergraduate students in a course on Art-Based Research. Sharing and analysing some of these disturbances help me to review my teaching positions, learning notions, assessment strategies, relationships with the students, uncertainties that emerged from the practice, and certainties that sometimes immobilize me in the teaching activities.
\end{abstract}

\section{Keywords}

self-narrative

pedagogical event

real learning

the unknown

reflexitivy 


\section{Starting scene: What does Arts-Based Research (ABR) in me mean?}

It is July 2015. Marina, an undergraduate student, presents her final paper to obtain the degree in Fine Arts to an examining commission. During her explanation on the narrative enquiry process focusing on her trajectory during her years at the university, she asks a rhetorical question: what does $\mathrm{ABR}$ in me mean? This produces resonances in me (Conle 19[K1]96) linked to my experiences as teacher and researcher at the university, and particularly on ABR. The emphasis of Marina 'in' her acts as disturbance on my own positionality. In me? On me? The preposition makes a fundamental difference. 'On' seems to refer to the surface of the self. 'In' opens up a journey into a deeper enquiry process, because it is linked with the unknown (Atkinson 2011), and could transform the experience of being a university teacher and researcher in a pedagogical event. The event is what affects me because it makes me feel disturbed, questioning my positions and stabilities.

\section{Situating the self in context}

The impact of Marina's statement connected with two previous research projects in the areas of disturbances in my teaching practice: one, around the experiences of the unknown on ABR classes with Fine Arts undergraduate students (Fendler and Hernández-Hernández 2013a); and, the other, based on a research project (2013PID$\mathrm{UB} / 001$ ) on the unknown in independent learning assessment, developed with other members from the innovative teaching group Indaga-t (Hernández-Hernández et al. 2015). Participating in these projects made me assume that everything that produces a 
disturbance can help to rethink my comfort zone (Brown 2008) at the university, and give me the opportunity of being more coherent as a teacher and researcher.

I am a professor of Cultural Pedagogies (Hernández-Hernández 2014) and ABR (Fendler and Hernández-Hernández 2013b) in a visual arts institution of higher education, and a member of the Esbrina research group (http://esbrina.eu/en/home/). In both cases I start my teaching and our research projects by giving an account of our experience and positionality on the topic of our interest from an auto-ethnographic approach (Hernández et al. 2010). Years ago, we decided that, while being academics ourselves, we could not investigate the experiences of others without first putting our own experiences under scrutiny. Under the effects of this act of epistemological, methodological and political coherence, we decided to start our research by writing autobiographical scenes linked to the issue we try to explore.

On remembering, reconstructing and turning autobiographical episodes into words or images, I have also shown to the others involved an undesired (or otherwise) examination of themselves. In my case, the others are not only the students but also the colleagues of the research and innovative teaching groups, and Rachel Fendler with whom I have shared, since 2010, the experience of teaching the ABR course.

\section{Being an academic as a disturbance experience}

Sharing my positionality in a research project and on a university course means, for example, giving an account of the glasses (biographical, epistemological and political) I use to cope with the uncertainty of the unknown. This is not a narcissistic or selfish experience, in order to provoke a situation of disturbance on the students, because it is an invitation to move from their comfort zone as listeners; and on myself, because I 
start with an act of performance where I expose myself through my doubts and expectations. Atkinson defines the idea of disturbance in teaching, 'when a teacher is confronted with something mysterious that disturbs his or her mode of functioning' (2012: 6). In my case, the disturbance comes from being involved in a situation of vulnerability in front of the students' expectations of what a class and a professor should be.

This idea of disturbance seems to be a central concept in philosophy and in authors such as Badiou (1988), Deleuze (2005) and Foucault (2012) among others. For me, the experience of disturbance is relevant because it seems to be connected with 'a rupture, a puncturing of ways of understanding or acting which has the potential to precipitate real learning' (Atkinson 2012: 6). In addition, what I would like to promote in the students and myself are experiences of real learning (Laur 2013) that 'involves a movement into a new ontological state; it defines a problem of existence, in contrast to more normative learning in its everyday norms and competences' (Atkinson 2012: 9). This approach is connected with the notion of 'pedagogical event' presented by Atkinson (2012), to whom 'an event' is a situation where 'a disruption of established ways of knowing, through learning events' emerges, 'modifying established patterns of understanding' (Atkinson 2012: 10).

The experience of a pedagogical event linked to a real-learning movement is what I try to promote in my encounter with the students. This movement takes place when young students and I, as teacher and also as learner, confront our standardized identities with experiences of real learning, which implies 'puncturing or modifying established patterns of understanding and assimilated configurations of knowledge on a local level. 
It is a process in which there is a firm challenge to see beyond current vistas of practice and formulate new ones' (Atkinson 2012: 9). It is, therefore, a movement that, in turn, attracts and disturbs me, but also allows learning otherwise. This movement takes place, for example, the day I shared with the group pages of my personal agenda. Through the conversation I showed how I was also coping with the cognitive conditions of capitalism created at the university during this time of restructuring. These pages showed no personal interests, only academic duties. I was reflecting with the students on the effects on my positionality of my working conditions, something that, until the event we were creating, was part of my personal sphere. However, we realized that the space of the ABR project offered us a possibility of resistance. The awareness of acting against the current state with the group, and through the collaborative research project was an act both of disturbance and empowerment.

Learning is, in our perspective, a 'slippery term, and quickly loses specificity when removed from scholastic objectives and sees its complexity reduced by a coding framework' (Fendler 2015). This approach seems connected with Atkinson's abovementioned movement to 'real learning'. This movement, I think, is what students experience when they are developing a research project in our classes, because they are able to 'produce a new alignment of thinking and action' (Atkinson 2012: 9). They experience learning as part of a subjectification process that generates 'a disruption of established ways of knowing, through learning events', because they are able 'to handle states of uncertainty as new knowledge and (where) new competences begin to emerge' (Atkinson 2012: 10).

When I acknowledge that the learning experience escapes the pedagogical norm, I assume a position of unknowing, confronting what we do not have access to, the 
shadows of learning that remain unseen. This position of uncertainty and disturbance creates an opportunity to use arts-based methods, becoming a tool to "pay attention in new ways' (Weber 2008: 44) to learning experiences in our encounters at the university classes.

\section{The experience of being student and teacher at the university in turbulent times}

From the tension arising between the normative frameworks and the risky position of learning the unknown through which I (with my colleague Rachel Fendler) traverse the pedagogical relationship, I wish to explore in this second part some of the situations where students' learning did, or did not, take place in our course on ABR. I should note that our enquiry strategy attempts to be coherent with the learning purpose of the course itself. Our research question asks how a course on ABR can change our understanding of learning, without avoiding the disturbances and tensions generated, on both teachers and students during that process.

As a professor who participates in the collaborative work developed in our class, I feel responsible for documenting, observing and finally assessing this process (along with the students and Rachel). As enquirer, I invested in understanding how we approach and frame this experience, in order to give meaning to it. During the process, we began to reflect on the type of pedagogical relationships established in a course on ABR, which invites students to learn to research by researching and generating a pedagogical event together.

The knowledge society as a framework for considering our experiences as students 


\section{and workers}

In the scholastic year 2014-2015, students of ABR decided to explore how the knowledge economy and cognitive capitalism affect them in their dual role of art students and workers, and how to give an account of this question through an enquiry process taking an ABR approach. The reason for this decision starts with the recognition that within the political and economic climate of the university today, this institution plays a crucial part in 'creating knowledge, administering and controlling the cycles of knowledge and the development of learning processes, but most of all on securing and regulating access to them' (Kaufmann 200[K2]1: 3). From this statement we recognize ourselves, students and teachers, as participants and subjects of this strategy of control. Within our research, we question our position as teachers/students and/or workers within the current economic and political context. We understand that the university and arts institutions have a different role than they had a few years ago, and as a result, the figures for students and teachers have changed.

One consequence is that artistic practices become products in a model where culture is a key player in neo-liberal systems. As a consequence of this analysis, we asked ourselves[K3]: what is cognitive capitalism? How does it affect us? Is the university a factory? How can we position ourselves politically within our research process? Can we research critically while also filling the role of the subject/object of study? To answer the questions - having shared our doubts, criticisms and life experiences - we decided to dedicate time in the class to reading Therese Kaufmann's (2001) text 'Art and knowledge: Towards a decolonial perspective'. In this text, Kaufmann interrogates the 
role of art and art production in societies where immaterial production is the basis of economic innovation.

In the following pages I present and reflect on my role as a teacher based on some scenes that students, Rachel and I considered meaningful, as exemplars of pedagogical events, during our learning process. I bring three perspectives to provide an account of this conversation. One given by the photographs, another from our common reflection on the research process (in Times New Roman) and the third shows my/our reflective process and its connection to concepts raised in the first part of this article (in Calibri). I hope this triangulation could offer a picture of some of my paths in my journey as a university professor.

\section{Scene1: Learning as creation of pedagogical events}

From the first moment, we invited students and ourselves by contributing personal experiences to generate a dialogue that went beyond the individual and began to resonate with a collective understanding of the situation. I recently read a paper (Biesta 2014) where the author explores Dewey's transactional theory of knowing, and invites moving the question of knowledge from the domain of certainty to the domain of possibility. I consider the beginning of a new course on $\mathrm{ABR}$ as a challenge of unexpected possibilities. In this opportunity, my focus was to bring the group (including myself) into situations capable of generating pedagogical events. Changing the arrangement of the classroom, avoiding a set teaching plan and starting the conversation sharing our own stories in the group was a form of disrupting students' normalized expectations (Figure 1). 


\section{Figure 1: The classroom as Agora, a site for possible encounters.}

[AR4]

At the beginning, instead of introducing ourselves and studying the syllabus, we interviewed each other, in pairs. We addressed each other as peers. We broke the ice. We looked for new ways of narrating and produced micro-narratives that addressed our relationships to work and the university. Because we did not have a fixed syllabus, Rachel began to share her field notes from the class each week in the virtual campus, and reminded everyone what was on the schedule for next week (Dorrego et al. 2015). Exploring this uncertain territory made me feel in a position of estrangement. Gazing at my image as part of the circle in the photography reinforces this impression, because in some way it leaves me in a position of vulnerability, when I expose myself to the gaze of others.

\section{Scene 2: Creating a collaborative environment for ABR}

When we decided the focus of the research, we moved to another room. The new environment generated a more horizontal and collaborative space for learning. In addition, more doubts, tensions and disturbances appeared. The experience of learning bec[K5]ame in some way a disruption in our manner of learning, creating the bases of a pedagogical event.

On the first day, Rachel and Fernando told us that once we had defined our research question, we would be able to work in a space that better suited our needs (Figures 2 and 3), and which was more intimate. Once we began working together, on one table, 
the dynamic changed. We challenged ourselves to work collaboratively. We knew what we did would be public, and that others would be able to see it and assess it. The classroom space generates ways of sharing and enquiring. Thus, we proposed a horizontal way of working and sharing, which required a high degree of commitment and responsibility, particularly when we decided to present our work at the conference, The 3rd Conference on Arts-based and Artistic Research, in Porto.

Figures 2 and 3: Researching and learning in a space of collaboration.

This day I was taking pictures, without staying in a set place. I took the responsibility of documenting the dance of the bodies in the room. Again, this situation makes me feel vulnerable, because students trust me as the depositary of the visual memory of the group. I move from details to a general view of our experience of learning. My gaze builds the representation of the group and creates the pedagogical event visually. I was part of the group, but also the teacher. Our journey was not a slow and relaxing float downstream; instead, it was marked by tense periods of silence, discontinuity in terms of the attendance of different group members, and, above all, doubts and the question addressed, in one way or another, to Rachel and me: Now what? These situations generate moments of disturbance where I felt lost inside the research and the learning process.

\section{What did we (I) gain from this research experience?}

What can we take away from the process I have tried to share here? What did we, students, Rachel and myself, learn about ABR? Have we learnt about alternatives ways 
of learning at the university? How have we journeyed collectively and individually through the research, and the course? What have I learnt giving an account of this trajectory about my trajectory as teacher and researcher?

Sharing and analysing our disturbances helped me to review our teaching positions, learning notions, assessment strategies; relationships with the students; uncertainties that emerged from the practice; and certainties that sometimes immobilize me.

I realized the need to redefine teachers' and students' roles and pedagogical relationships; to redefine roles concer[K6]t to questioning the responsibilities and commitments that we assume as teachers and students. It means moving our role from a transmitter to a participant who is accompanying the student's achievements, mistakes and improvements, and implies understanding that students are the main actors of their learning process.

During the case presented we have attempted to understand ourselves, not from a quotidian perspective but from a different logic. To do so we generated alternative practices that did away with individualism, identifying our histories and transforming them into experiences by narrating them to our peers. We enquired into how we are represented, by others (especially by the university) and by ourselves. This meant we had to leave behind an established path in order to build a new one, or at least attempt to.

The course on ABR became a space for acting, resisting and reinventing. It followed a non-normative logic, in an effort to think and construct our gaze critically, in our particular space and time. The resources provided by ABR allowed us to connect, and 
above all understand, the bridges between the personal and the political, the intimate and what we share with others.

I was able to confirm that $\mathrm{ABR}$ introduces an alternative to other ways of researching and acknowledges the experiential and subjective. In our research, we understood artistic processes as a critical apparatus for dialoguing with the images and representations that surround us. We understood that we were working from the border between fields, demarcating an alternative, or a resistance, to hegemonic languages, both within research and the arts.

Finally, writing this article has been an exercise in revealing how the learning experience - as possibility - assists us to adopt a position of unknowing. By rejecting a prefix and planning a notion of learning, I must rethink my position in the university using a different rationale, alternative to the hegemonic culture that imposes a logic of efficiency - that inspired by the need to control that which emerges from and is diluted in the experience of each student and, also, myself.

This positionality was, in one way or other, in my agenda since I arrived at the university some decades ago. Now, by learning with the students, and generating practices of resistance in front of the current neo-liberal conditions of the University, I look not only to the present but to the end of my academic career. I feel far from the romantic demiurge figure of the artist and teacher represented in social imaginaries. I also do not share the cynicism of some of my colleagues. I firmly believe the university needs to be reconfigured in another direction beyond the neo-liberal one, opening up to work with social movements and groups who are fighting social inequality. This is the place where I would like to be in the following years.

\section{References}


Atkinson, D. (2011), Art, Equity and Learning. Pedagogies against the State, Rotterdam: Sense.

(2012), 'Contemporary art in education: The new, emancipation and truth', The International Journal of Art \& Design Education, 31:1, pp. 5-18.

Badiou, A. (1988), L'Être et l'Événemen/Being and Event, Paris: Seuil.

Biesta, G. (2014), 'Pragmatising the curriculum: Bringing knowledge back into the curriculum conversation, but via pragmatism', The Curriculum Journal, 25:1, pp. 2449.

Brown, M. (2008), 'Comfort zone: Model or metaphor?', Australian Journal of Outdoor Education, 12:1, pp. 3-12.

Conle, C. (1996), 'Resonance in preservice teacher inquiry', American Educational Research Journal, 33:2, pp. 297-325.

Deleuze, G. (2005), Lógica del sentido/The Logic of Sense, Barcelona: Paidós.

Dorrego, N., Fendler, R., Gaitan, J., González, P., Gritane, A., Gutiérrez, A., Hernández-Hernández, F., Riera, M. and Vaquero, M. (2015), 'The experience of being in the university in turbulent times: Learning and doing arts-based research', The 3rd Confere[K7]nce on Arts-Based Research and Artistic Research, Porto, Portugal, January, 
http://3c.nea.fba.up.pt/sites/3c.nea.fba.up.pt/files/FINAL_abr-turbulenttimes_universityofbarcelona.pdf.

Fendler, R. (2015), 'Tracing the eventful space of learning: In and out of a collaborative ethnography with youth', AERA2015, Chicago, Ap[k8]ril.

Fendler, R. and Hernández-Hernández, F. (2013a), 'What does research mean for Fine Arts students?', in F. Hernández-Hernández and R. Fendler (eds), 1st Conference on Arts-Based and Artistic Research: Critical Reflections on the Intersection of Art and Research, Barcelona: University of Barcelona, pp. 227-32. [K9]http://hdl.handle.net/2445/45264.

(2013b), 'What remains unseen: Negotiating the grey areas of collaborative learning in a course on arts-based research', International Society for Education through Art (InSEA) European Regional Congress, Canterbury, UK, Jun[K10]e.

Foucault, M. (2012), ‘¡Hablar sin miedo!’/‘Speaking without fear!’, in F. A. Marulanda (ed.), Michel Foucault: Interconexiones de Poder y de Conocimiento: ¡Hablar Sin Miedo!/Michel Foucault: Interconnections of Power and Knowledge: Speaking without fear!, Ossining, NY: Leiris Publishing/Editorial Leiris, pp. 237-52.

Hernández-Hernández, F. (2014), 'Pedagogias Culturais: o processo de (se) constituir em um campo que vincula conhecimento, indagaçâo e ativismo'/'Cultural pedagogies: The process of constituting a field where knowledge, inquiry and activism are linked', 
in R. Martins and I. Tourinho (eds), Pedagogias Culturais/Cultural Pedagogies, Santa Maria, Brasil: Editora ufsm, pp. 329-56.

Hernández, F., Sancho, J. M., Creus, A. and Montané, A. (2010), 'Becoming university scholars: Inside professional auto-ethnographies', Journal of Research Practice, 6:1, Article M7,[K11] http://jrp.icaap.org/index.php/jrp/article/view/204/188.

Hernández-Hernández, F., Sancho, J. M. and Fendler, R. (2015), 'Las zonas grises de estudiantes y docentes como acontecimiento: Aprender de lo que nos perturba'/‘The grey zones of students and teachers as event: Learning from what disturbs us', REIRE, Revista d'Innovació i Recerca en Educació, 8:2, pp. 368-79.

Kaufmann, T. (2001), 'Art and knowledge: Towards a decolonial perspective', Instituto Europeo para políticas culturales progresistas, http://transversal.at/transversal/0311/kaufmann/en. Accessed 12 October 2014.

Laur, D. (2013), Authentic Learning Experiences: A Real-World Approach to ProjectBased Learning, New York: Routledge.

Weber, S. (2008), 'Visual images in research', in J. G. Knowles and A. L. Cole (eds), Handbook of the Arts in Qualitative Research, Thousand Oaks, CA: Sage, pp. 41-53.

\section{Contribut[K12]or details}

Contac[K13]t:

Cultural Pedagogies Unit, Fine Arts Faculty, University of Barcelona, Spain. 